\title{
Fostering Employee's Service Quality and Customer Satisfaction: Evidence from Emerging Pakistan
}

http://doi.org/10.21272/bel.3(3).47-67.2019

\section{Farhan Muhammad Muneeb}

Doctoral Student of Business Administration, School of Management, Xi'an Jiaotong University, China

\section{Muhammad Salman Chughtai}

Doctoral Student of Management Sciences, International Islamic University, Islamabad, Pakistan

\section{Uzma Anjum}

MS Student of Business Administration, COMSATS Institute of Information Technology, Virtual Campus, Islamabad, Pakistan

\section{Jiyun Ma}

MSc Student of Management, UCD Michael Smurfit Graduate Business School, Dublin, Ireland

\begin{abstract}
Providing quality services is a key condition for the stable functioning of companies in a changing environment. Given the fact that delivering exceptional quality services deemed to foster firm competitiveness, worldwide service quality and customer satisfaction captivate serious considerations from across the globe. An analysis of literary sources allows us to conclude that customer satisfaction and service quality have long-term predictors to enhance firms' values. Employee service quality plays a significant role in satisfying customer's needs in these digital times not only to accomplish firms' particular objectives but also to socialize firms globally - to sustain customer's confidence among competitors. The relevance of solving this scientific problem lies in the lack of research work, which highlighted functional aspects of employee's service quality, yet numerous firms from across the globe are pugnacious to progress services, deteriorating money on ill-conceived service daily-routine packages and undermining credibility with management rhetoric not supported up with some strategic actions. Thus, this study aims to bring a deeper insight view, bonding employee's service quality and customer satisfaction. A survey distributed on a sample of 278 customers of Telecom industry through electronic and simple forms. A statistical package social science (SPSS) was conducted to calculate the collected data. The results of data analysis revealed that three out of five predictor variables 'assurance', 'responsiveness', and 'reliability' have a significant impact on customer satisfaction while 'empathy' and 'tangibility' have an in-significant impact on customer satisfaction. According to the results of the study, it was concluded that ensuring customer satisfaction in changing conditions becomes a strategic prerequisite for creating competitive advantages of the company, improving the quality of customer service, in the context of easing pressure on profitability and achieving strategic long-term goals of the company. Therefore, this study peculiarly predicts that employee's service quality is a crucial antecedent of customer satisfaction explicitly within the context of Telecom Industry in emerging Pakistan.
\end{abstract}

Keywords: Service Quality, Customer satisfaction, Telecom industry of Pakistan, Profitability, Economic instability.

JEL Classification: D11, L16.

Cite as: Muneeb, F.M., Chughtai, M.S., Anjum, U., Ma, J. (2019). Fostering Employee's Service Quality and Customer Satisfaction: Evidence from Emerging Pakistan. Business Ethics and Leadership, 3(3), 47-67. http://doi.org/10.21272/bel.3(3).47-67.2019.

(C) The Authors, 2019. This article is published with open access at Sumy State University.

\section{Introduction}

Telecom industry of Pakistan focusing on service quality dimensions and satisfaction attitude of customers (YES/NO) whether service quality dimensions impact on customer satisfaction in the Telecom industry of Pakistan or not? The beginning of telecommunication services in Pakistan can be traced back to 1947 that made a major change in 1962 when telegraph and telephone services were split up by the establishment of 
independent $\mathrm{t} \& \mathrm{t}$ and postal department. Later on, developments were made in the provision of telecommunication services to the customer on a regular basis but from the last two decades extensive changes in the telecom sector have taken place with the launch of mobile telephony. In this digital age of growth and progress that had a great impact on its subscribers who became more conscious about the service quality. Providing magnificent service quality and attaining customer satisfaction is the foremost and challenging issue facing by the modern service industry (Hung et al., 2003). Customer satisfaction is explained as an "evaluation of the perceived discrepancy between prior expectations and the actual performance of the product" (Wilton, 1988; Oliver, 1999). Customer's satisfaction with products and services of a company is observed as the most influential factor leading towards competitiveness and success (Hennig-Thurau and Klee, 1997). There are numerous amounts of studies that empirically investigated the relationship between these concepts, reporting significant influence that service quality exerts on customer satisfaction. The most familiar definition of service quality is the differentiation customers make between their expectations and judgments about the received service (Parasuraman et al., 1988). It is easy to find out many studies related to service quality in the literature. One of the significant reasons for concentrating on the service quality in the literature is the importance of service quality on companies success (Martinez Care and Martinez Garcia, 2007; Negi, 2009; Santouridis and Trivellas, 2010; Santos, 2003). Consumers analyze service quality by comparing what they desire or expect to what they really get or perceive they are getting (Berry et al., 1988). However, service quality is often measured using the instrument, developed by (Parasuraman et al., 1985; 1988). We will examine service quality dimensions and customer satisfaction in the telecom sector. The focus is to recognize which service quality dimensions are important to customer's satisfaction of telecom industry.

The significance of this study is to distinguish critical factors guaranteeing effective customer satisfaction. The research findings will look ahead to fill the gap in the literature and to provide effective guidance for academics and practitioners about service quality and customer satisfaction relationship in the telecom industry. This research study will help to explore out the key variables that are having a strong influence on customer satisfaction in the telecom sector and will affect the purchasing decision of customers and develop the sense of belonging and brand loyalty among customers. The study will help the department which provides services to their customer it can be bank, hospital, educational institutions, hotel, etc. Up till now, researches have made significant researches on Service Quality (SQ) and Customer Satisfaction (CS). In 2013, S. Markovic, S. Raspor Jankovic presented four dimensions of Service Quality (SQ) reliability, empathy, accessibility, and tangibles. In this study, the research findings are looking forward to filling the gap in the literature, and to provide useful guidance for practitioners and academics regarding service quality and customer satisfaction relationship in the Telecom Industry of Pakistan.

The objective of this study is threefold: first, to investigate the relationship between service quality and customer satisfaction in Emerging Pakistan; second, to explore the impact of service quality dimension and customer satisfaction within the context of telecom industry of Pakistan; third, to formulate the recommendations for telecom industry for service quality for customer satisfaction.

\section{Literature Review}

\subsubsection{Customer Satisfaction (CS)}

Competitiveness nowadays has a significant place for the improvement of quality and customer's satisfaction in the telecom industry. In the environments where there is no competition, that's to say when demand exceeds than the supply, sometimes company offers their consumers unsatisfactory services because of the idea that the customers have no other alternatives and they will agree upon the current services unconditionally. But if we talk about the competition it totally depends on how much customer sticks towards the firm, it is possible only when the customer is satisfied with the desired services. Customer satisfaction is of great importance because it gives business owners and marketers with a structure that they can use to organize and refine their businesses. Customer satisfaction can be interpreted as the feeling that a person experiences when offered services meet up to their expectations. According to Deng et al., (2009) the capability of a service provider to create satisfaction of high degree and it is crucial for product differentiation and establishing a strong relationship with customers. Customer satisfaction makes the consumers faithful to one of Telecommunications Company. Prior researchers have observed that satisfaction of the consumers can help the brands to form a long and profitable link with their customers (Eshghi, Haughton and Topi, 2007). 
Literature accepts that customer satisfaction is an essential element for long-term business success (Zeithami et al., 1996). To protect or obtain market shares, the company needs to outperform than its competitors by providing high-quality service or product to guarantee the satisfaction of customers (Tsoukatos and Rand, 2006). Other sectors also focus on customer satisfaction likewise in banks. Banks also need to recognize customer's service demands and how it will affect on service delivery and customer's point of view (Gerrard and Cunningham, 2001), for a minimum increment of customer satisfaction that can lead to loyalty and retention of the customer (Bowen and Chen, 2001). For a preferable understanding of consumer's point of view, companies have to decide their actions which require meeting the customer's needs. Companies have to recognize their own strengths and weaknesses, where they stand with comparative competitors and to figure out ways for future improvement and progress (Magesh, 2010). In the banking industry, a fundamental element of customer satisfaction is the nature of the connection build between the customer and the provider of the services and products. Thus, both service quality and product are commonly noted as a critical prerequisite for satisfying and retaining valued customers (Muslim and Isa, 2005). It is actually true that to deliver high service quality to consumers offers companies an opportunity to discriminate themselves in competitive markets (Karatepe et al., 2005).

Customer's interest is also important, as when purchaser considers the product importance and utilizes time to find information then it eventually increases the satisfaction level (Russell-Bennett, McColl-Kennedy, and Coote, 2007). The satisfaction may influence the concerned company by repurchase, purchase of more products, positive word of mouth and willingness of the customer to pay more for the particular brand. Any business is likely to lose market share, customers and investors if it fails to satisfy customers as effectively and efficiently as its competitors do (Anderson, Fornell, and Mazvancheryl, 2004). As Turel and Serenko (2006) stated that, customer's satisfaction with high level, have a tendency to buy again and more tolerance to price changes. Prior studies discover the direct relationship between service quality and satisfaction (Cronin and Taylor, 1992; Cronin and Taylor, 1994; Cronin et al., 2000; Keaveney and Parthasarathy, 2001; Lim et al., 2006; Shin and Kim, 2008; Parasuraman, et al, 1988). Cronin et al. (2000), state that acceptable service quality perceptions enhance satisfaction. Literature about Satisfaction also associates with switching intentions and service quality. Studies also show that service quality has a direct impact on behavioral attitudes through satisfaction (Cronin et al., 2000). According to Shin and Kim (2008), the quality of perceived service is high, satisfaction will be high and then switching ratio of the customers will also be low. In addition to the direct relationship, Cronin et al. (2000) also suggested an indirect relationship between service quality and behavioral intentions. They stated that service quality has an important effect on behavioral intentions via satisfaction.

Consumer's satisfaction and service quality are interconnected, and this creates worth for the customer. If consumers are provided with the services that they assume, this will surpass their expectation, and the customer will have a constructive view of the organization. Furthermore, if customers feel they got not much value than what they presumed their attitude regarding a given firm will be negative and they may transfer this attitude to potential consumers (Chau \& Kao, 2009). If satisfaction exists, then customers will become faithful towards firm but if customers are unsatisfied their loyalty is not guaranteed. Hence a special focus should be given by the management on the satisfaction and this starts with delivering quality service (Mohsan et al., 2011). Scholars made a general agreement that the concept of service quality and customer satisfaction is extremely interrelated. For example, it has been observed good service quality generally results in a high-level satisfaction of customers' in the telecommunication industry, restaurants, and healthcare (Messay, 2012). It has also been observed that service quality (SQ) is converted into an important factor in the industry of banking, as they too are in the service industry. Due to rising trends in technology and in customer awareness, customers have become progressively demanding (Ghost \& Gnanadhas, 2011).

\subsubsection{Service Quality (SQ)}

Service quality is one of the most fundamental research topics for the past few decades (Gallifa \& Batalle, 2010). Service Quality can be explained as for how well the Services are delivered to the consumer's expectations. Perceived Service quality can be defined as the customer's perception of the overall quality or superiority of a product or services with respect to its intended purpose. So, it is concluded that if perceived service is equal to expected services customer will be satisfied and if the perceived services are less than expected services customer will be dissatisfied. Service providers often assess the service quality provided to their customers, in order to improve their quality, to quickly identify drawbacks, and to improve client satisfaction in a better way. The idea of service quality was proposed in the 1980s when the organization understands that only quality product maintains a competitive edge (Boshoff and Gray, 2004). Significant 
ISSN (online) - 2520-6311; ISSN (print) - 2520-6761

research has been performed on customer satisfaction and service quality; as these elements are playing a fundamental role in company's success in a competitive market (Oh and Parks, 1997; Nadiri and Hussain, 2005).

Previously, it has been observed that quality as a computable aspect for tangible products only. And the reason was due to the deficiency of the service sector in the economy. Due to the growing significance of the service sector in the economy, the service quality measurement began to be of interest for the individuals in this field (Ghost \& Gnanadhas, 2011). Quality services are not only a significant element of customer satisfaction in manufacturing industries but also in developing service firms nowadays (Karim \& Chowdhury, 2014). It is specified by many types of research that Customer satisfaction plays a very important role in retention and consumer loyalty; however, this is not the surety of repeat purchase (Mohsan et al., 2011). Firms nowadays in the service sector want to struggle through service quality. Customer satisfaction is one of the important elements, which influence by the quality of services (Timothy, 2012). Service quality enables firms to measure and to compare before and after changes, quality-related issues can be identified, clear standards for service delivery can be established. Improvement in customer satisfaction and by giving High service quality, will give a firm an edge in the market share and in getting attractive profit (Hossan, 2012).

Many researchers have focused their attention on the nature of the relationship between service quality and customer satisfaction. Nowadays, with the growing competition in organizations, service quality has become an admired zone of academic exploration and has been accepted as a focused competitive edge and supporting constructive relationships with customers (Zeithmal, 2000). Customers all over the world have become more quality-aware; therefore, consumer demands for good quality service have been increased (Lee, 2005). Service sector such as the telecom sector is compelled to provide excellent services to their customers in order to have a sustainable competitive advantage. Service quality has been interpreted as the complete assessment of service by the customers (Eshghi et al., 2008). Various professionals define service quality as the variance between customer's expectations for the service experienced and the perceptions of the service received (Munusamy et al., 2010). Service Quality is not only important for the Telecom industry but for other sectors also. Likewise, It has been found that positive experience of service quality has an important impact on student satisfaction and therefore satisfied student would attract more students through word-of-mouth communications (Alves \& Raposo, 2010). Ahmed \& Nawaz (2010) stated that service quality is a significant performance measure in educational excellence and is a fundamental strategic variable for universities to build a strong perception in the customer's mind. Cronin et al. (2000) stated that service value has a mediator impact on service quality.

For measuring the consumers' perceptions SERVQUAL model is used, the identified five dimensions of SERVQUAL model are reliability, assurance, tangibles, empathy, and responsiveness, which is relative to customer's expectations. Depending on the nature of their business, some businesses may measure two or three of the dimensions (Taiwo et al., 2012). It is easy to calculate product quality as compared to service quality. This is due to the reason that service quality is made up of unique characteristics (Messay, 2012). Between all the models for quantifying service quality, the most accepted and applied model in diversity of industries is the SERVQUAL (service quality) model developed by Parasuraman et al. The SERVQUAL model of Parasuraman et al. (1988) proposed a five-dimensional model of service quality reliability, empathy or competence of staff, responsiveness, tangibles and assurance as the instruments for measuring service quality (Parasuramanet el al., 1988; Zeithamlet el al., 1990). Service quality includes of five dimensions: Reliability (ability to perform the promised service dependably and accurately), Responsiveness (willingness to help customers and provide prompt service), Empathy (caring and individual attention the firm provides its customers), Assurance (knowledge and courtesy of employees and their ability to inspire trust and confidence), and Tangibles (appearance of physical facilities, equipment, personnel and written materials). Reliability is considered as an important key to service quality. Other dimensions will be significant to customers only if a service is reliable because other dimensions cannot repay for unreliable service delivery (Berry et al., 1994).

\subsubsection{Reliability (REL)}

Reliability is defined as the ability to deliver the assured service dependably and accurately. Capability to execute the promised service dependably and accurately (Armstrong, 2012). Reliability depends on tackling customer's service-related problems; performing services right the first time; delivering services at the promised time and keeping an error-free track record. Furthermore, they declared reliability as the most 
significant factor in conventional service (Parasuraman et al., 1988). If a company is providing good services, a company and its staff should be ready to respond to consumer's queries about products and services offered (Ojo, 2010). According to Toosi and Kohonali (2011), timely responses to requests is one of the important customer's expectations. Therefore, this should not be delayed or ignored simply because these are fundamental issues. Online support is an offer by some companies that provide customers with an instant resolution to their queries. Email requests and phone calls should be examined on a case-by-case basis and responded to accordingly (Sakhaei et al., 2014). Reliability also comprises of accurate order accomplishment, accurate data, accurate quote, exact in billing, accurate in the computation of commission, keep services promise and also mentioned that reliability is the most important factor in banking services (Yang et al., 2004).

\subsubsection{Assurance (AS)}

Assurance is basically courtesy, competence, credibility; security of the firm employees gives to its customer. Parasuraman et al. (1985) interpreted assurance as knowledge to have the courtesy of employees and their competency to inspire confidence and trust. A business, which engages people who like their work, attracts customers and act as a source of motivation. If the Company's representatives provide genuine and caring service, customers would want to do business (Angelova \& Zekir, 2011). According to Sadek et al. (2010), in British banks assurance means the well-mannered and friendly employees, allocation of financial advice, inside comfort, without any difficulty having access to the account information and has well informed and qualified management team.

\subsubsection{Tangibility (TAN)}

Tangibility can be interpreted as the Appearance of physical facilities, equipment, personnel, and communication materials. Parasuraman et al. (1985) defined tangibility as the appearance of physical facilities, staff, equipment, and written materials. Ananth et al. (2011) mentioned for tangibility in their study of private sector banks as modern looking equipment, employees are well dressed, physical facility and materials are apparently appealing. Gbadeyan and Gbonda (2011) pointed out that frontline of any business is the employees, interacting with the customers and to represent the firm on a day to day basis. If employees'neglect or mistreats customers, the customer doesn't always make a complaint about what they experience as impersonal service. Rather than this, the customer will never return and undoubtedly, no business wants this something like that (Klemz \& Boshoff, 2011).

\subsubsection{Empathy (EMP)}

Empathy can be interpreted as the Care, individualized concentration the company provides to its customers. Individualized attention, caring a firm offers to its customers (Armstrong, 2012). Customer and Employee interactions are reflected in the dimension of empathy (Armstrong, 2012). Customers have a presumption regarding the services provided to them and have expectations on how the service providers are concerned and recognize about their individual needs and wants. As a service provider, make an effort to figure out the situation from the consumer's point of view which gives a clear picture of what is happening (Toosi \& Kohonali, 2011). Gbadeyan and Gbonda (2011) proposed that to attract customers through caring is a key determinant and by providing variety in the features of service products that will fulfill their wants and need in the marketplace. Parasuraman et al. (1985) defined empathy as the care and individual attention the firm provides its customers. It involves giving consumer personal attention and it is the responsibility of the employees to recognize the needs of their customers and to provide convenience in business hours. Ananth et al. (2011) are mentioning about empathy in their study on private sector banks, individual giving attention, appropriate operating hours, giving personal concentration, chief interest in heart and try to understand customer's specific requirements.

\subsubsection{Responsiveness (RES)}

Responsiveness defined as the readiness or willingness of employees to provide service or immediate response to the customer need. Customers highly appreciate to provide service in a timely manner; this aspect should be understood by the good service providers (Iqbal et al., 2010). Moreover, organizations that value efficiency and pay attention towards the services that they are offering, so that it can give them an advantage and by using this advantage to keep off competitors (Karim \& Chowdhury, 2014). Responsiveness is the idea to show the flexibility and ability to modify the service as per user's need. It involves the timeliness of services (Parasuraman et al., 1985). It is also involves understanding demands and 
desires of the customers, appropriate operating hours, individual concentration given by the staff, attention to the issues of the customer, safety in their transaction (Kumar et al., 2009).

\subsection{Theory and Conceptual Framework}

Most of the prior studies about Service Quality and Customer Satisfaction were started in early 1980'z. The SERVQUAL service quality model was originated by a group of American authors, 'Parsu' Parasuraman, Valarie Zeithaml, and Len Berry, in 1988. It puts focus on the main elements of high-quality service. The SERVQUAL authors originally find out ten elements of service quality, but in the upcoming work, these were split up into five elements. A. Parasuraman, Valarie A. Zeithaml, \& Leonard L. Berry (1994) give 10 dimensions: Access, Communication, Competence, Courtesy, Credibility, Reliability, Responsiveness, Security, Tangibles, and Understanding (knowing the Customer). They are again limited to five elements: reliability, assurance, tangibles, empathy, and responsiveness. It is shown in the figure below:

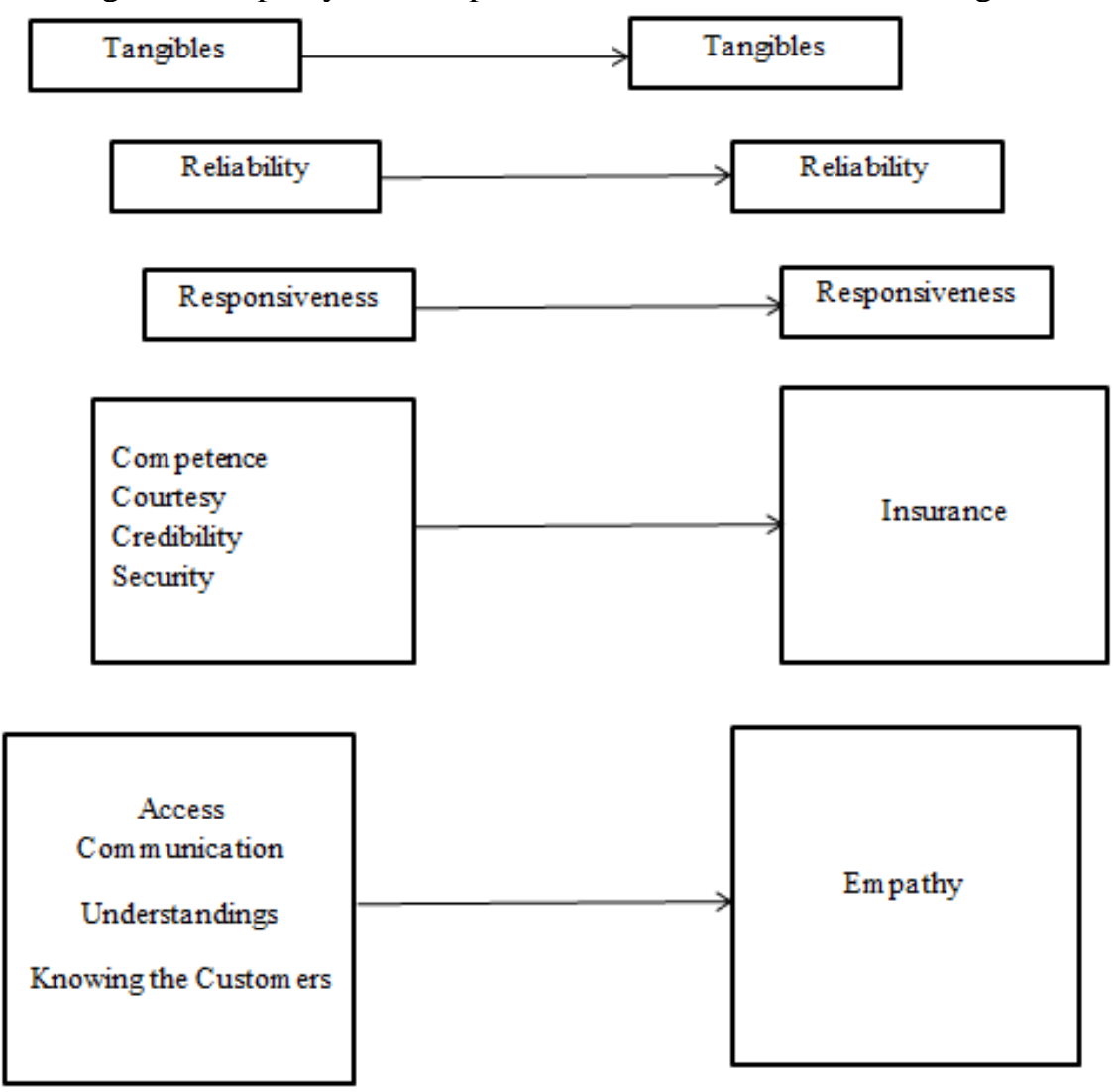

Figure 2.1 Service Quality Dimension Model

Source: Own elaboration of the authors

Niveen El Saghier, Demyana Nathan, in 2013 using the same research model. The results are of significant importance, which enables bank managers to have a right understanding of customer's perception of service quality of banking and accordingly how to improve their satisfaction with respect to aspects of service quality. In 2013, S. Markovic, S. Raspor Jankovic are exploring the relationship between Service Quality and Customer Satisfaction in Croatian Hotel Industry. But they use four variables of Service Quality Reliability, Empathy and competence of staff, Accessibility and Tangibles. In 2014, Kitapci, Olgun, Ceylan Akdogan, and İbrahim Taylan Dortyol have research on the effects of Service Quality Dimensions on Patient Satisfaction, in the Public Healthcare Industry. The objective of this study is to investigate the outcomes of service quality (SQ) dimensions on satisfaction, recognizing the effect of satisfaction on word of mouth (WOM) communication and repurchase intention (RI) and exploring an important relationship between WOM and RI. By delivering Service Quality (SQ) and improving Customer Satisfaction, help service providers to distinguish the offering. This study has selected the work of Parasuraman et al.'s SERVQUAL variables.

\subsection{Critical Analysis of Literature}

Service quality (SQ) can be computed in terms of customer expectation, customer perception, customer attitude and customer satisfaction (Sachdev \& Verma, 2004; Ekinci, 2003). However, some of the authors 
have a point of view which says that the quality of service can be explained from the different assumption of users regarding the services provided with the perception of the service received (Munusamy et al., 2010). The idea of service quality was proposed in the 1980s when the organization understands that only quality product maintains a competitive edge (Boshoff and Gray, 2004). Various professionals define service quality as the variance between customer's expectations for the service experienced and the perceptions of the service received (Munusamy et al., 2010). The SERVQUAL model of Parasuraman et al. (1988) proposed a five-dimensional model of service quality reliability, empathy or competence of staff, responsiveness, tangibles assurance and as the instruments for measuring service quality (Parasuramanet el al., 1988; Zeithamlet el al., 1990). Customer loyalty towards the brand, profit, and loss of the company totally depends upon the Service Quality (SQ). According to Fečiková (2004), customer satisfaction regarding the quality of certain services will decide the company's success or failure. 'Reliability' is defined as the ability to deliver the assured service dependably and accurately. Furthermore, they declared reliability as the most significant factor in conventional service (Parasuraman et al., 1988). 'Assurance' as knowledge to have the courtesy of employees and their competency to inspire confidence and trust. Parasuraman et al. (1985) defined 'Tangibility' as the appearance of physical facilities, staff, equipment, and written materials. Parasuraman et al. (1985) defined 'Empathy' as the care and individual attention the firm provides its customers. 'Responsiveness' is defined as the readiness or willingness of employees to provide service or immediate response to the customer need. 'Customer satisfaction' (CS) can be interpreted as the feeling that a person experiences when an offering service meets up to their expectations. According to Deng et al., (2009) the capability of a service provider to create satisfaction of high degree and it is crucial for product differentiation and establishing a strong relationship with customers. It is actually true that to deliver high service quality to consumers offers companies an opportunity to discriminate themselves in competitive markets (Karatepe et al., 2005).

\subsection{Literature Gap}

Researchers have done a lot of research on Service Quality (SQ) and Customer Satisfaction (CS) but still, there are few ranges in this subject need to be covered. Each researcher extended the variables in the model, which is commonly used for service quality (SQ) according to their needs. In 2014, Kitapci, Olgun, Ceylan Akdogan, and İbrahim Taylan Dortyol work in the Public Healthcare Industry. The purpose of this research was to have an analysis of the effects of dimensions of service quality on satisfaction and the effects of satisfaction on repurchase intentions and on word-of-mouth communication for outpatients in Turkey. Furthermore, this study explores the association among the variables and provided statistical evidence regarding their significance. Although the major purpose for conducting this research is to learn by using a recommended research model, how service quality dimensions have an effect on satisfaction, the study itself is also connected to a wide range of service provider companies that concentrate their efforts on making long-term relationships with patient. In 2013, El Saghier, Niveen, and Demyana Nathan do their research at banks in Egypt. The research outcomes are that Customer Satisfaction in Egyptian banking services is especially affected by Reliability, Empathy, Assurance, and Responsiveness. This research evaluated the quality picture of banking customers in Egypt and the variance in the relative importance they have connected to the various quality dimensions by utilizing the SERVQUAL model. SERVQUAL looks to be an authentic scale to measure banking service quality and gives a convenient diagnostic role to play in evaluating and monitoring service quality in banks. In 2013, Marković, Suzana, and Sanja Raspor Janković work on the service quality and customer satisfaction in the Croatian hotel industry. The motive of this study was to find out the relationship between customer satisfaction and service quality. The results of this study show that hotel service quality is indeed an important predictor of customer satisfaction. Thus, by making better hotel service quality, will result with a high satisfaction level of hotel guests.

Tremendous work is done on Service quality (SQ) and Customer Satisfaction (CS) in different fields. In this study, the researcher will use the recommended model and dimension to check the impact of Service Quality and Customer Satisfaction in the Telecom Industry of Pakistan.

\section{Research Framework}

The research framework for this research consisted of five predictor variables under one dimension and one criterion variable. 


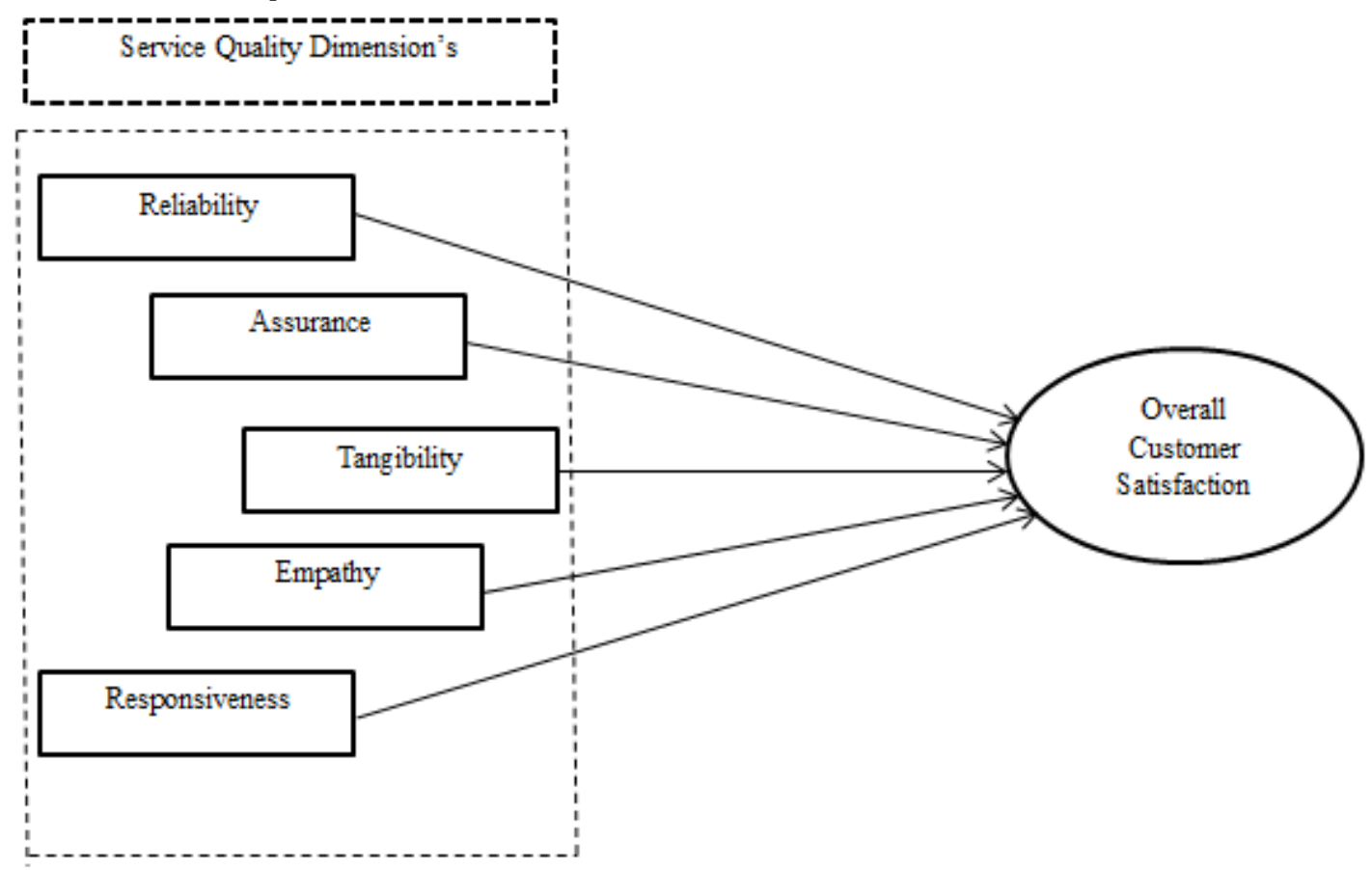

Source: Markovic \& Jankovic, 2013

Figure 3.1 Framework by Markovic \& Jankovic, 2013

H1a: Reliability has a positive and significant impact on overall customer satisfaction.

H1b: Responsiveness has a positive and significant impact on overall customer satisfaction.

H1c: Empathy has a positive and significant impact on overall customer satisfaction.

H1d: Assurance has a positive and significant impact on overall customer satisfaction.

H1e: Tangibility has a positive and significant impact on overall customer satisfaction.

\section{Research Methodology}

\subsection{Research Design}

The framework that the researcher uses to answer the research problem, and which helps in methods and procedures of data collection and its analysis (Zikmund, 1997). Exploratory, descriptive and explanatory are the designs in which research can be categorized (Neuman, 2003). This research will be descriptive in nature because according to Gall et al. (2007) the focus of descriptive research is on 'what is' rather than the examination of some intervention.

The descriptive design is used in this research because the researcher wanted to find the relationship of predictor variables of Service Quality with five dimensions reliability, empathy or competence of staff, responsiveness, tangibles and assurance with criterion variable (Overall Customer Satisfaction).

According to Neuman (2003), research design can be categorized in cross-sectional and longitudinal in terms of time. The researcher used cross-sectional research design in this research because according to Bryman (2004) in cross-sectional design we can collect information on variables at a solitary point in time. Cost of cross-sectional design research is low because it studies and gets data from the current existing ongoing system (Hussey \& Hussey, 1997). That is why the researcher selected cross-sectional and statistical design.

\subsection{Sample Design}

The research was related to Telecom industry of Pakistan. So, it shows the unit of analysis of the research on the customers of Telecom industry of Pakistan. The complete gathering of particular community components significant to the exploration bunch is known as target population (Zikmuand, 2003). The whole gathering of objects of interest that is characterized by the research destinations is called target population (Zikmund, 1999). 
The target population of this research was the Customers of Telecom Industry of Pakistan. The reason to select the Telecom Customer's as a population was to determine the effects of Service Quality on Customer Satisfaction in the Telecom industry of Pakistan. A lot of research has done on Service Quality and Customer Satisfaction in all over the world but in Pakistan a lot to be done. Telecom Industry of Pakistan is growing with a rapid speed, which provides quality services at low prices. But there were some areas that should be addressed which can enhance the quality and performance of the Telecom industry of Pakistan.

\subsubsection{Population Frame}

The population frame of this consisted of the following steps. Firstly, there was the whole population means all customers of the telecom industry in Pakistan. Secondly, the researcher identified the target population which was the Telecom industry customers in Rawalpindi and Islamabad. Thirdly, identified the customer's experienced Telecom services in Rawalpindi and Islamabad, Lastly, identified the total number of customers as shown in Figure 4.1.

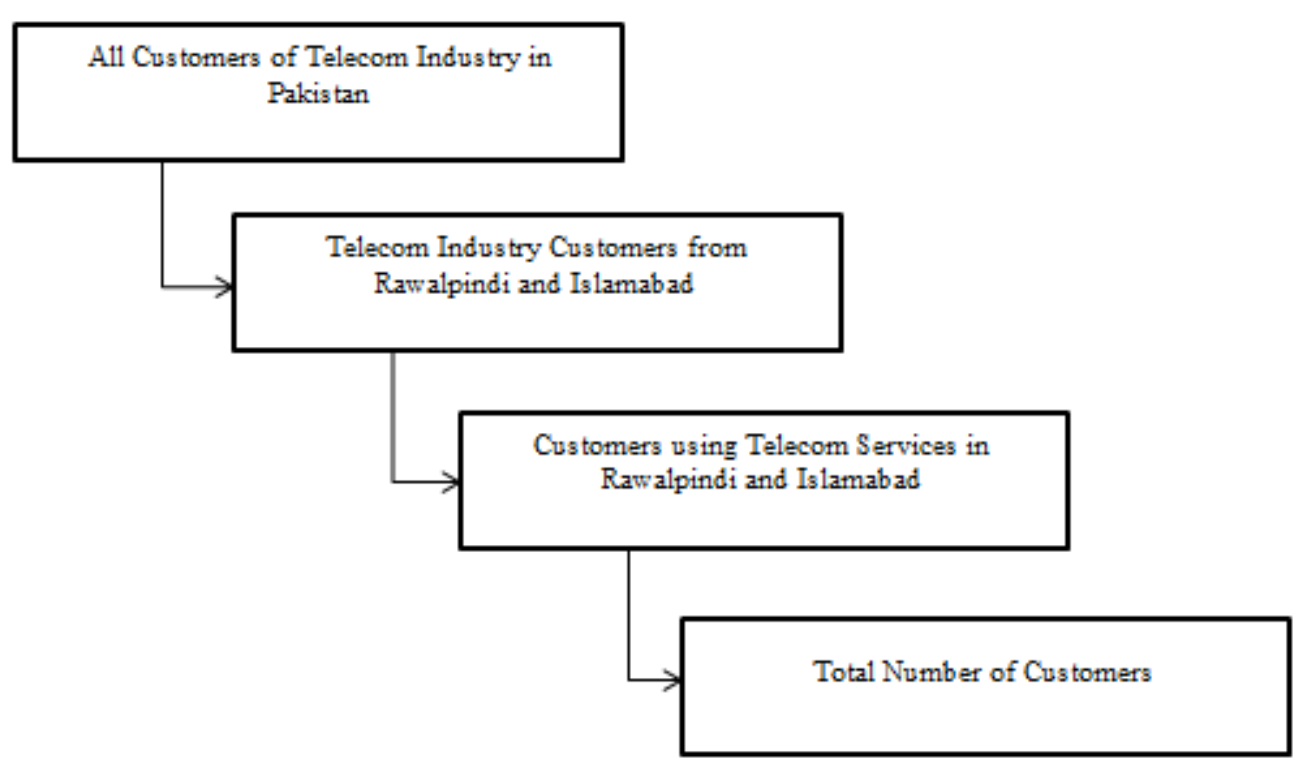

Source: Own elaboration of the authors

Figure 4.1 Population frame

\subsubsection{Sample Selection}

The population will be the Customers from the Telecom Sector of Pakistan. Customers from telecom sector of Rawalpindi and Islamabad are taken. There are approximately 1000 customers who are taken from different telecom sectors of Rawalpindi/Islamabad. The total collection of elements, which one would like to study or make inferences, is known as a population. The individual participant on which the measurement is taken is known as population element. It is the unit of study (Cooper \& Schindler, 2011).

From a given population, the number of elements selected is known as the sample size. According to Mugenda and Mugenda (2003) how large a sample should be is a function of the variation in the population parameters under study and the estimating precision needed by the researcher. Survey Software (2014) as there is approximately 1000 population than the sample size will be 278 with a $95 \%$ confidence level.

\subsection{Instrument}

The following instruments of this research were utilized

1. Overall Customer Satisfaction Dimension (OCS);

2. Service Quality Dimension (SQ);

2.1 Reliability feature (REL);

2.2 Assurance feature (AS);

2.3 Tangibility feature (TAN);

2.4 Empathy (EMP);

2.5 Responsiveness feature (RES). 
Business Ethics and Leadership, Volume 3, Issue 3, 2019

ISSN (online) - 2520-6311; ISSN (print) - 2520-6761

\subsubsection{Variables and Measurements}

The study focused on critical factors which impact on customer satisfaction in the Telecom industry of Pakistan.

\section{Demographic Variables}

There were four demographic variables include Telecom industry Customer, gender, age and User of Telecom product in Rawalpindi and Islamabad. Telecom industry Customer is computed utilizing alternatives while the user of Telecom Product computed utilizing five alternatives scales.

\section{Dependent and Independent Variables}

Overall Customer Satisfaction (OCS) was the only criterion variable of this research. Customer satisfaction can be interpreted as the feeling that a person experiences when offered services meet up to their expectations. Collins Cobuild English Dictionary (1999) defined satisfaction as it is the joy that one individual feels when she/he does something or gets something that she/he needed or expected to do or get. Customer satisfaction plays a very important role in retention and consumer loyalty; however, this is not the surety of repeat purchase (Mohsan et al., 2011). According to Kim, Park, and Jeong (2004), customer satisfaction is a consumer's reaction to the state of satisfaction, and consumer's judgment of satisfaction level.

Service quality is one of the most fundamental research topics for the past few decades (Gallifa \& Batalle, 2010). Service Quality can be explained as for how well the Services are delivered to the consumer's expectations. The SERVQUAL model of Parasuraman et al. (1988) proposed a five-dimensional model of service quality reliability, empathy or competence of staff, responsiveness, tangibles assurance and as the instruments for measuring service quality (Parasuramanet el al., 1988; Zeithamlet el al., 1990).

Reliability (REL) is defined as the ability to deliver assured service dependably and accurately. Capability to execute the promised service dependably and accurately (Armstrong 2012). If a company is providing good services, a company and its staff should be ready to respond to consumer's queries about products and services offered (Ojo, 2010).

Assurance (AS) is basically courtesy, competence, credibility, security of the firm employees gives to its customer. Parasuraman et al. (1985) interpreted assurance as knowledge to have the courtesy of employees and their competency to inspire confidence and trust. A business, which engages people who like their work, attracts customers and act as a source of motivation.

Tangibility (TAN) can be interpreted as the Appearance of physical facilities, equipment, personnel, and communication materials. Parasuraman et al. (1985) defined tangibility as the appearance of physical facilities, staff, equipment, and written materials. Ananth et al. (2011) mentioned for tangibility in their study of private sector banks as modern looking equipment, employees are well dressed, physical facility and materials are apparently appealing.

Empathy (EMP) can be interpreted as the Care, individualized concentration the company provides to its customers. Individualized attention, caring a firm offers to its customers (Armstrong, 2012). Customer and Employee interactions are reflected in the dimension of empathy (Armstrong, 2012). Gbadeyan and Gbonda (2011) proposed that to attract customers through caring is a key determinant and by providing variety in the features of service products that will fulfill their wants and need in the marketplace.

Responsiveness (RES) defined as the readiness or willingness of employees to provide service or immediate response to the customer need. Responsiveness is the idea to show the flexibility and ability to modify the service as per user's need. It involves the timeliness of services (Parasuraman et al., 1985).

\subsubsection{Scales Treatment}

A Likert scale but more commonly pronounced as a psychometric scale commonly involved in research employing questionnaires. The 5 focuses Likert scale was utilized as a part of this exploration. Telecom industry customers were asked for that response to the clarification using a five-point Likert scale going from 1 to 5 where 1 shows strongly disagree (Sdis), 2 for disagree (Dis), 3 for neutral (Neu), 4 for agreeing (Agr) and 5 for strongly agree (Sage).

\subsection{Questionnaires}

Data collected through questionnaires, which were designed in such a way to get the desired information of customer satisfaction related to Service quality in Telecom industry of Pakistan. It focused on examining the variables that can influence customer satisfaction with service quality dimension. Close-ended questions of 5 
Business Ethics and Leadership, Volume 3, Issue 3, 2019 ISSN (online) - 2520-6311; ISSN (print) - 2520-6761

points Likert scale was used to acquire data about the respondent's level of affirmation to investigate and uncover the effect of service quality on customer satisfaction in the Telecom industry of Pakistan.

In the designed questionnaire, the questions one to four consisted of demographic questions like age, gender, customers of Telecom industry of Pakistan and customers of Rawalpindi and Islamabad. The questions five to thirty-three consisted of dependent and independently related questions which to be answered from Likert scale 1 to 5 . The dependent variable perceived Customer satisfaction had nine questions in the questionnaire Roger Hallowell (1995).

Customer satisfaction was measured in that way the first measure consists of responses to a single question on the customer-satisfaction questionnaire: "Overall, how satisfied are you with ... [Telecom industry staff]?" Responses for all satisfaction questions were made on 1-5 Likert-type scales labeled, where 1 shows strongly disagree (Sdis), 2 for disagree (Dis), 3 for neutral (Neu), 4 for agreeing (Agr) and 5 for strongly agree (Sta). The problems associated with the use of a single response variable were mitigated by the simplicity of the question, and Yi's (1990) suggestion that a single overall satisfaction measure scored as this one was is "reasonably valid".

And the independent variables Reliability (1) Room Roshnee Ramsaran-Fowdar (July 2006), Assurance (2) Room Roshnee Ramsaran-Fowdar (July 2006), Tangibility (3) Room Roshnee Ramsaran-Fowdar (July 2006), Empathy (4) Rooma Roshnee Ramsaran-Fowdar (July 2006), Responsiveness (5) Rooma Roshnee Ramsaran-Fowdar had questions in the questionnaire.

\subsection{Applications}

Statistical Package for the Social Sciences versions 22 and Microsoft Excel 2010 was utilized for information examination. The information was moved into the Statistical Package for the Social Sciences sheet for data analysis. To check the reliability, validity, hypothesis testing and relationship between criterion and predictor variables the following tests were applied on the collected data. Cronbach's Alpha Reliability Coefficient, Descriptive statistics, Standard Deviation and Mean, Correlation Matrix, Multiple Regression.

\subsection{Descriptive Statistics}

Descriptive statistics consisting of frequency, the percentage of respondent response, Cronbach's $\alpha$ reliability coefficient, mean, standard deviation, correlation and multiple regression among the variables, which were included in this research.

Table 5.1 Gender ( $\mathrm{N}=255)$

\begin{tabular}{|l|c|c|}
\hline \multicolumn{1}{|c|}{ Gender } & No. of respondents (N) & Percentage \\
\hline Male & 135 & 52.9 \\
\hline Female & 120 & 47.1 \\
\hline
\end{tabular}

Source: Own elaboration of the authors

Table 5.1 demonstrates the number of respondents concerning gender. It shows that $135(52.9 \%)$ are males and $120(47.1 \%)$ are females.

Table 5.2 Age $(\mathrm{N}=255)$

\begin{tabular}{|l|c|c|}
\hline \multicolumn{1}{|c|}{ Age } & No. of respondents (N) & Percentage \\
\hline $20-30$ & 130 & 51 \\
\hline $31-40$ & 67 & 26.3 \\
\hline $41-50$ & 38 & 14.9 \\
\hline 51 -above & 20 & 7.8 \\
\hline
\end{tabular}

Source: Own elaboration of the authors

The above Table 5.2 shows the number of respondents with respect to the age group. The above Table 5.2 data shows that $130(51 \%)$ respondents have age 20-30, $67(26.3 \%)$ respondents have age 31-40, and 38 (14.9\%) respondents belong to 41-50 age group, 20 (7.8\%) respondents having age 51-above.

Table 5.3 Company name $(\mathrm{N}=255)$

\begin{tabular}{|l|c|c|}
\hline \multicolumn{1}{|c|}{ Company name } & No. of respondents (N) & Percentage \\
\hline Mobilink/Jazz & 38 & 14.9 \\
\hline Ufone & 57 & 22.4 \\
\hline Telenor & 40 & 15.7 \\
\hline Zong & 39 & 15.3 \\
\hline Warid & 35 & 13.7 \\
\hline Ptcl & 38 & 14.9 \\
\hline Others & 8 & 3.1 \\
\hline
\end{tabular}

Source: Own elaboration of the authors 
ISSN (online) - 2520-6311; ISSN (print) - 2520-6761

Table 5.3 divides the number of respondents with respect to the company's name they are using the services off. The above Table 5.3 shows that 38 (14.9\%) respondents are using Mobilink/Jazz; 57 (22.4\%) respondents are using Ufone; $40(15.7 \%)$ respondents are using Telenor; $39(15.3 \%)$ respondents are using Zong; $35(13.7 \%)$ respondents are using Warid; 38 (14.9\%) respondents are using PTCL; 8 (3.1\%) respondents are using the services of Others companies.

Table 5.4 Customer belongs to $(\mathrm{N}=255)$

\begin{tabular}{|l|c|c|}
\hline \multicolumn{1}{|c|}{ Institute of study } & No. of respondents (N) & Percentage \\
\hline Rawalpindi & 139 & 54.5 \\
\hline Islamabad & 116 & 45.5 \\
\hline
\end{tabular}

Source: Own elaboration of the authors

Table 5.4 demonstrates that the respondents belong to which city either Islamabad or Rawalpindi. The above Table 5.4 demonstrates that the 139 (54.5\%) respondents belong to Rawalpindi, 116 (45.5\%) respondents belong to Islamabad.

\subsubsection{Reliability and Validity}

To evaluate the internal consistency or inward stability of a scale Cronbach's alpha was utilized. Higher the alpha worth is better (Garson, 2008c). If $\alpha$ is greater than 0.7 it is sufficient (Teo, 2009). Pedersen \& Nysveen (2003) elaborated that the value of $\alpha$ ought to be in excess of 0.7. Cronbach's $\alpha$ measures the degree to which thing reactions acquired in the meantime correspond profoundly with one another (Garson, 2008b). In any case, great reliability ought to create no less than a coefficient estimation of 0.70 . It fluctuates from 0 to 1 (Pallant, 2001). In particular, a high alpha is possible even though the item responses are multidimensional (Schmitt, 1996).

Table 5.5 Alpha reliability coefficients

\begin{tabular}{|l|c|c|}
\hline \multicolumn{1}{|c|}{ Variables } & Items & Cronbach's $\boldsymbol{\alpha}$ \\
\hline Customer Satisfaction & 9 & .87 \\
\hline Reliability & 5 & .76 \\
\hline Assurance & 5 & .71 \\
\hline Tangibility & 5 & .79 \\
\hline Empathy & 5 & .91 \\
\hline Responsiveness & 5 & .91 \\
\hline
\end{tabular}

Source: Own elaboration of the authors

The above findings demonstrate the Cronbach's alpha $\alpha$ reliability coefficient of 5 independent variables and a dependent variable of this research. It shows that all variables had an acceptable level of reliability. Variable 'Empathy' (0.919) had the highest value of $\alpha$ reliability coefficient whereas variable 'Assurance' (0.712) had the lowest value of $\alpha$ reliability coefficient.

Validity is frequently distinguished because the degree to which an instrument calculates what it intimates to calculate. It is connected with the thing whether the findings are truly about what they show up to be about. The material of these observations was approved by selecting the variables associated and exploited already as a section of the writing (Churchill \& Iacobucci, 2004). The five variables reliability, assurance, tangibles, empathy and responsiveness, expertise in Management was requested to review the questionnaire before data collection.

Construct validity displays the degree to which evolves theoretically identify with each other to compute an idea taking into account the hypothesis basic an examination (Zikmund, 2000). The evaluation ought to exhibit discriminate and convergent validity to attain established validity. Things that are pointing out to calculate the similar build is connected obviously with each other are called convergent validity. The association of lattice and between build connections were broke down for United and discriminate legitimacy. Research meets the model and makes the tool sufficiently legitimate to be utilized as a part of the main study (Malhotra, 1999). 


\subsubsection{Standard Deviation (SD) and Mean}

Table 5.6 Descriptive statistics

\begin{tabular}{|l|c|c|c|c|c|}
\hline \multicolumn{1}{|c|}{ Variables } & N & Min & Max & Mean & Std. Dev \\
\hline Customer Satisfaction & 255 & 1.00 & 5.00 & 3.49 & 0.84 \\
\hline Reliability & 255 & 1.00 & 5.00 & 3.46 & 0.86 \\
\hline Assurance & 255 & 1.00 & 5.00 & 3.45 & 0.88 \\
\hline Tangibility & 255 & 1.20 & 5.00 & 3.10 & 0.98 \\
\hline Empathy & 255 & 1.00 & 5.00 & 3.83 & 1.03 \\
\hline Responsiveness & 255 & 1.00 & 5.00 & 3.880 & 0.96 \\
\hline
\end{tabular}

Source: Own elaboration of the authors

Table 5.6 demonstrates the total numbers of samples $\mathrm{N}=255$, the minimum value of scale is 1 whereas the maximum value is 5. The variable "Responsiveness" has the highest mean 3.880784 whereas the variable "Tangibility" has the lowest mean 3.102745. The variable "Empathy" has the highest value of standard deviation 1.033994. On the other hand, "Customer's Satisfaction" has the lowest standard deviation 0.844569 .

\subsubsection{Correlation Matrix}

Correlation analysis was used to examine the nature of the relationship among each service quality dimension and overall customer satisfaction.

Table 5.7 Correlations among variables

\begin{tabular}{|c|c|c|c|c|c|c|}
\hline Variables & 1 & 2 & 3 & 4 & 5 & 6 \\
\hline 1.Customer Satisfaction & $(.93)$ & & & & & \\
\hline 2.Reliability & $.448 * *$ & $(.87)$ & & & & \\
\hline 3.Assurance & $.458 * *$ & $.672 * *$ & $(.84)$ & & & \\
\hline 4.Tangibility & .063 & .036 & .100 & $(.89)$ & & \\
\hline 5.Empathy & $.425 * *$ & $.597 * *$ & $.628 * *$ & .114 & $(.95)$ & \\
\hline 6.Responsiveness & $.445^{* *}$ & $.543 * *$ & $.567 * *$ & $.136^{*}$ & $.858 * *$ & $(.96)$ \\
\hline
\end{tabular}

**. Correlation is significant at the 0.01 level (2-tailed).

**. Correlation is significant at the 0.05 level (2-tailed).

Diagonal Bold values demonstrate the Square root of $(\boldsymbol{\alpha})$

Source: Own elaboration of the authors

Table 5.7 demonstrates the outcome of correlation( $\mathrm{r}$ ) between dependent and independent variables. Assurance has $(r=0.458)$ the greatest $r$ to criterion variable Customer Satisfaction. The other predictor variables which are correlated with criterion variable have the values, Reliability has $(r=0.448)$, Responsiveness $(r=0.445)$, Empathy has $(r=0.425)$ and Tangibility has $(r=0.063)$. They all are significant at a p-value less than 0.05 .

Table 5.7 demonstrates the current study result of correlation(r) among criterion variable Customer's Satisfaction (CS) and predictor variables.

\subsubsection{Multiple Regression Analysis}

Multiple regression analysis was utilized in this research for testing the hypotheses. Five predictor variables and one criterion variable Customer's Satisfaction (CS) were derived from previous research (Sun et al., 2008) and used in this research. Multiple regression analysis outcomes are demonstrated in Table 5.8. All hypotheses are significant at a confidence level of less than $90 \%$ and $95 \%$.

Table 5.8 Correlation(r) comparisons

\begin{tabular}{|l|c|}
\hline \multicolumn{1}{|c|}{ Independent Variables } & Current Research \\
\hline Reliability & 0.448 \\
\hline Assurance & 0.458 \\
\hline Tangibility & 0.63 \\
\hline Empathy & 0.425 \\
\hline Responsiveness & 0.445 \\
\hline
\end{tabular}

Source: Own elaboration of the authors 
Table 5.9 Multiple regression results

\begin{tabular}{|c|c|c|c|c|c|c|}
\hline \multicolumn{7}{|c|}{ Coefficients } \\
\hline \multirow{2}{*}{\multicolumn{2}{|c|}{ Model }} & \multicolumn{2}{|c|}{ Unstandardized Coefficients } & \multirow{2}{*}{$\begin{array}{c}\text { Standardized Coefficients } \\
\text { Beta } \\
\end{array}$} & \multirow{2}{*}{ T Values } & \multirow{2}{*}{ Sig. } \\
\hline & & B & Std. Error & & & \\
\hline \multirow[t]{6}{*}{1} & (Constant) & 1.400 & .250 & & 5.603 & .000 \\
\hline & Reliability & .188 & .075 & .192 & 2.512 & .003 \\
\hline & Assurance & .199 & .075 & .209 & 2.647 & .009 \\
\hline & Tangibility & .004 & .047 & .005 & .090 & .928 \\
\hline & Empathy & -.034 & .092 & -.042 & -.370 & .712 \\
\hline & Responsiveness & .225 & .092 & .257 & 2.439 & .005 \\
\hline
\end{tabular}

Dependent Variable: Customer Satisfaction.

Source: Own elaboration of the authors

Table 5.10 Anova results

\begin{tabular}{|c|l|c|c|c|c|c|}
\hline \multicolumn{2}{|c|}{ Model } & Sum of Squares & df & Mean Square & F & Sig. \\
\hline \multirow{2}{*}{1} & Regression & 50.448 & 5 & 10.090 & 19.229 & $.000^{\mathrm{b}}$ \\
\cline { 2 - 7 } & Residual & 130.654 & 249 & .525 & & \\
\cline { 2 - 7 } & Total & 181.103 & 254 & & & \\
\hline
\end{tabular}

a. Dependent Variable: Customer Satisfaction

b.Predictors: (Constant), Responsiveness, Tangibility, Reliability, Assurance, Empathy

Source: Own elaboration of the authors

Table 5.11 Model summary

\begin{tabular}{|c|c|c|c|c|}
\hline Model & R & R Square & Adjusted R Square & Std. Error of the Estimate \\
\hline 1 & $.528^{\mathrm{a}}$ & .279 & .264 & .724 \\
\hline
\end{tabular}

a. Predictors: (Constant), Responsiveness, Tangibility, Reliability, Assurance, Empathy

Source: Own elaboration of the authors

The three hypotheses H1, H2, H5 belong associated with Reliability, Assurance and Responsiveness respectively have a significant impact on overall Customer satisfaction. To check the significance among criterion variable Customer satisfaction (CS) with Reliability, Assurance and Responsiveness all the hypotheses $\mathrm{H} 1, \mathrm{H} 2$, and $\mathrm{H} 5$ respectively are found to be significant at "P" less than 0.05 ' with $\beta$ is equal to $.192, .209$ and .257 respectively. Hypothesis H3: Tangibility have a non-significant effect on Customer Satisfaction (CS) in the Telecom industry of Pakistan is at $(\beta=0.005, \mathrm{p}>0.05), \mathrm{H} 4$ : Empathy also have a non-significant effect on (CS) Customer's Satisfaction in Telecom Industry of Pakistan with values $(\beta=-$ $0.42, \mathrm{p}>0.05)$.

The dimension 'Responsiveness' $(\beta=0.257, \mathrm{p}<0.05)$, had the highest statistically significant standardized coefficient. Therefore, this was the most important independent variable and had the highest impact on overall customer satisfaction. This was followed by the dimensions 'Assurance' $(\beta=0.209, \mathrm{p}<0.05)$, and 'Reliability' $(\beta=0.192, p<0.05)$, 'Tangibility' $(\beta=0.005, p>0.05)$ and 'Empathy' $(\beta=-0.42, p>0.05)$ this dimension had a minimum impact on overall customer satisfaction. In addition, this impact was not statistically significant.

The multiple regression analysis discloses the following results. The relationship between the combination of independent variables in the model and the dependent variable is strong $(R=0.528)$. According to the coefficient of determination ( $\mathrm{R} 2=0.279$ ) and adjusted coefficient of determination (adjusted $\mathrm{R} 2=0.264$ ), the five service quality dimensions explained approximately 26 percent of the variance in overall customer satisfaction. Since R2 value and adjusted R2 value are very similar (adjusted R2 decreased for only 0.015 points), the regression model in this research has very good explanatory power of the dependent variable. In addition, the significant $F$-ratio $(\mathrm{F}=19.229, \mathrm{p}<0.01)$.

Table 5.12 Hypotheses summary

\begin{tabular}{|c|l|c|}
\hline Dependent variable & \multicolumn{1}{|c|}{ Independent variables } & Significant \\
\hline \multirow{4}{*}{ Customer_Satisfaction (CS) } & Reliability (REL) & Yes \\
\cline { 2 - 3 } & Assurance (AS) & Yes \\
\cline { 2 - 3 } & Tangibility (TAN) & No \\
\cline { 2 - 3 } & Empathy (EMP) & Yes \\
\cline { 2 - 3 } & Responsiveness (RES) & \\
\hline
\end{tabular}

Source: Own elaboration of the authors 


\section{Discussion and Conclusion}

The discussion based on the factors which impact on Customer's satisfaction in Telecom industry of Pakistan. Dimensions included in the research are reliability, assurance, tangibles, empathy, and responsiveness. In this study, researcher formed 5 hypotheses to be tried utilizing exact proofs. By multiple regression analysis, it is proved that three out of five variables have powerful domination on criterion variable i.e. Customer's satisfaction (CS). The acknowledgment and dismissal of hypothesis were taking into account statistical measure. There is a good level of representativeness in selected predictor variables as the quality of this standard demonstrates.

Correlation analysis was utilized to explore the nature of the link among each Service quality dimension and overall customer satisfaction. In order to find out the respective impact of Service quality dimensions on overall customer satisfaction. The multiple regression analysis was performed. For executing this analysis, the main research hypothesis was tested. For this purpose, five dimensions extracted in exploratory factor analysis were applied as independent variables and overall customer satisfaction as the dependent variable

In-Service Quality dimension Reliability (REL) has a positive and significant effect on Customer's Satisfaction (CS) in Telecom industry of Pakistan. Reliability analysis was performed. Results (Table 5.5) showed that Cronbach's alpha coefficients of the extracted factors ranged from 0.712 to 0.919 . That is well above the minimum value is 0.60 , which is considered acceptable as an indication of scale reliability (Hair et al., 2006). Thus, these values purpose good internal consistency of the factors. Finally, Cronbach's alpha value for the overall perceptions scale indicates its high reliability. Therefore, "reliability", "accessibility", "tangibles" "empathy", and "responsiveness", can be regarded as reliable underlying dimensions of Service Quality in the Telecom industry of Pakistan. In addition, the variable "Responsiveness" has the highest mean 3.880 whereas the variable "Tangibility" has the lowest mean 3.102. The variable "Empathy" has the highest value of standard deviation 1.033. On the other hand, "Customer's Satisfaction" has the lowest standard deviation 0.844 .

Correlation analysis showed positive and significant relationships between each dimension of service quality and overall customer satisfaction. This evidence supported the hypotheses H1b, H1a, and H1e. Dimensions "Assurance", "Reliability" and "Responsiveness" are strongly related, while H1d and H1c "Empathy" and "Tangibles" were moderately related to overall customer satisfaction. These results purposed that increase in each service quality dimension is likely to lead to an increase in overall customer satisfaction. Similar findings were also found in the context of the hotel industry in Nepal (Pandey and Joshi, 2010), Malaysia (Fah and Kandasamy, 2011), Jordan (Al Khattab and Aldehayyat, 2011).

Multiple regression analysis suggests that Service quality is an essential antecedent of overall customer satisfaction. The results show a strong, positive and remarkable relationship between the combination of service quality dimensions and overall customer satisfaction. The dimension 'Responsiveness' had the highest statistically significant standardized coefficient. Therefore, this was the most important independent variable and had the highest impact on overall customer satisfaction. This was followed by the dimensions 'Assurance' and 'Reliability' also have a significant impact on Customer's Satisfaction 'Tangibility' and 'Empathy' these two dimensions had the minimum impact on overall customer satisfaction. In addition, this impact was not statistically significant.

The study evaluates that indeed there is a strong relationship between the 'Responsiveness' and customer satisfaction, meaning that Telecom industry responsiveness is also an important contributor towards customer satisfaction in the Telecom industry of Pakistan. The study further concludes that employees of ideal Telecom industry will inform customers exactly when services will be performed, and they will give prompt services to customers. In the same consideration, employees of ideal Telecom industry will always be willing to help customers.

The most important predictor of overall customer satisfaction in this study was the dimension 'Assurance'. Thus, employees having a courteous attitude towards the customer, Ability of employees to instill confidence in customers and to trust company services and knowledgeable staff who can answer customer's questions had the significant impact on overall customer satisfaction. Courtesy and Knowledge of employees and their ability to inspire trust and confidence in customer increases overall satisfaction in the customers of Telecom industry of Pakistan. 
ISSN (online) - 2520-6311; ISSN (print) - 2520-6761

Furthermore, 'Reliability' appeared to be the third dimension by the importance of influencing overall customer satisfaction in this study. Hence, the study results lead to a conclusion that the reliability of the Telecom industry in providing services to its customers at a promised time is a key contributor towards customer satisfaction. Moreover, it can be also concluded that there are high expectations of customers that the ideal Telecom industry will perform the promised service dependably and accurately. Similarly, it can be concluded that ideal Telecom industry employees show a sincere interest in solving customer's issue, perform the services right the first time, Telecom industry Staff have good communication skills and the Telecom industry employees will maintain error-free records. It also indicates that customerse perception is highest in the reliability area this result showed consistency with Parasuraman et al. $(1985,1988)$ and Yang et al., (2004) and lowest in the assurance area.

Finally, although correlation coefficient between dimension 'Tangibility' and 'Empathy' and overall customer satisfaction implied significant correlation when these dimensions were involved in the model, these two dimensions did not have a statistically significant impact on overall customer satisfaction.

Moreover, all regression models were statistically significant. Choi and Chu (2001) reported that all seven independent variables (dimensions) in the regression model had an important impact on overall customer satisfaction. Regression model tested by Fah and Kandasamy (2011) consisted of four of the five independent variables that significant effect on customer satisfaction. Three out of five independent variables in the present research were found statistically significant. The greatest impacts on overall customer satisfaction had "staff service quality" (Choi and Chu, 2001), "tangibility" (Fah and Kandasamy, 2011), and "accessibility" (present study).

Based on the presented results, the authors believe that the multiple regression model can be considered as strong evidence that improvements in Telecom industry service quality dimensions result in higher overall customer satisfaction. Telecom industry practitioners who want customer satisfaction level to be increased they should emphasize the excellence in providing reliable, assured and responsive services that are delivered by empathetic and visually appealing facilities. Thus, according to the present study, courtesy, competence, employee's interpersonal skills, ability to convey promised service at right time and their willingness and skillfulness to resolve customer's complaints will be appreciated by customers. Knowing the comparative importance of each Service quality dimension can help Telecom industry practitioners to deploy resources more effectively. This allows them to pay their concentration on those dimensions that have a significant impact on customer satisfaction, and to improve others.

\subsection{Recommendations}

The fruitful recommendations to implement in future are:

1. The Telecom industry in Pakistan has to ensure that they will remain reliable to their customers if indeed they need to remain competitive in the market. Telecom industry can achieve reliability this by introducing back up services to provide services accurately and timely.

2. The study recommends the need for Telecom industry to innovate new ways of improvement in the way they respond to customer requests so as to avoid service breakdowns. This can be achieved easily through the new communication channels such as the Internet or mobile telecommunication.

3. Assurance is the factor that attracts the customer towards the company and makes it brand loyal, the factors involved in it is the courtesy, to inspire customer, to build confidence and trust factor in the customer. This can be achieved by giving employees proper professional training regarding maintaining Quality Services and how to deal with the customer.

4. The study also focuses on Telecom industry customers. Telecom industry needs to consider empathy as one of the important points in enhancing customer satisfaction. This can be effectively achieved through the creation of a specific department for such issue that can handle such issues of the Telecom industry to give them individual attention so that they are able to build the confidence of the customers at the Telecom industry Services.

5. Tangibility is the factor how attractive physical facilities, modern equipment, visually appealing broachers, neat appearance of employees This can be achieved by giving clean and attractive atmosphere at service centers or touchpoints where customer interact with the companies. The employees should try to maintain their professional appearance. 


\subsection{Limitation and Future Research}

In spite of the fact that this examination speaks to a cautious and systemic push to consolidate components of Service Quality, it is not without limits, although, the present research also has some limitations that should be cognized. The limitations consider in this regard are limited geographical area, sampling procedure, and structure for considering the service quality dimensions. The convenience sampling procedure may have resulted in the sample that does not represent all the characteristics of the target population. Likewise, the Service quality on the overall services of the Telecom industry is considered but now in the present world the focus of the people regarding services is different, somebody is interested in wired internet services other will be in wireless $3 \mathrm{G}$ or $4 \mathrm{G}$. So the future research can be focused on specifying the one services or by taking any specific department which is involved in providing service quality or by taking specific company because there might be a possibility that customer is satisfied with the services of one not from other. This research focuses on the Customers of Rawalpindi and Islamabad for the feedback, in future research the Customers of another area should also be included. Nevertheless, these limitations cannot deny the significance of reported results as a whole. They serve to provide suggestions for future research. Therefore, future research should consist of a more representative sample in order to ensure more comprehensive results. What is more, other aspects of hotel Telecom industry service quality should be taken into account. Therefore, the future model should include attributes like other factors which may influence Customer Satisfaction due to Service Quality are brand loyalty and price fairness. This would ensure a more precise and applicable survey for the Telecom industry as a whole. So, further studies to be carried out on customers of different cities of Pakistan to establish the impact of service quality on customer satisfaction. This can be determined by keeping in view that difference in customers' perceptions and expectations and services offered.

\section{References}

1. Agyapong, G. K. (2011). The effect of service quality on customer satisfaction in the utility industry - A case of Vodafone (Ghana). International Journal of Business and management, 6(5), 203-210.

2. Ahn, J.H., Han, S.P., and Lee, U.S. (2006). Customer churn analysis: Churn determinants and mediation effects of partial defection in the Korean mobile telecommunications service industry. Telecommunications Policy, 30, 552-568.

3. Al Khattab, S.A. and Aldehayyat, J.S. (2011). Perceptions of Service Quality in Jordanian Hotels. International Journal of Business and Management, 6(7), 226-233.

4. Berry, L. L., Parasuraman, A., \& Zeithaml, V. A. (1988). The service-quality puzzle. Business horizons, 31(5), 35-43.

5. Bryman, A. (2004). Social Research Methods, Oxford University Press, Oxford.

6. Choi, T. Y., \& Chu, R. (2001). Determinants of hotel guests' satisfaction and repeat patronage in the Hong Kong hotel industry. International Journal of Hospitality Management, 20(3), 277-297.

7. Churchill, G.A. Jr. and Iacobucci, D. (2004). Marketing Research: Methodological Foundations, 9th ed., Southwestern Publications, Cincinnati, OH.

8. Cooper, D. R. \& Schindler, P. S. (2001). Business Research Methods. 7th ed. McGraw Hill International Edition. USA.

9. Cooper, D. R. \& Schindler, P. S. (2011). Business Research Methods, 11th ed., USA: McGraw-Hill Irwin International Edition.

10.El Saghier, Niveen, and Demyana Nathan (2013). Service Quality Dimensions and Customers' Satisfactions of Banks in Egypt. Proceedings of 20th International Business Research Conference, Dubai, UAE.

11.Englewood ClMohsan, F., Nawaz, M. M., Khan, M. S., Shaukat, Z., \& Aslam, N. (2011). Impact of customer satisfaction on customer loyalty and intentions to switch: Evidence from banking sector of Pakistan. International Journal of Business and Social Science, 2(16), .iffs, NJ: Prentice-Hall.

12.Fah, L.K. and Kandasamy, S. (2011). An investigation of service quality and customer satisfaction among hotels in Langkawi. Proceedings of International conference on management (ICM 2011), Penang, Malaysia, pp. 731-749.

13.Gallifa, J., \& Batallé, P. (2010). Student perceptions of service quality in a multi-campus higher education system in Spain. Quality Assurance in Education, 18(2), 156-170.

14.Gbadeyan, R. A., \& Akinyosoye-Gbonda, O. O. (2011). Customers'preference for e â [euro] banking services: A case study of selected banks in Sierra Leone. Australian Journal of Business and Management Research, 1(4), 108. 
Business Ethics and Leadership, Volume 3, Issue 3, 2019

ISSN (online) - 2520-6311; ISSN (print) - 2520-6761

15.Gall, M. D., Gall, J. P., \& Borg, W. R. (2007). Educational research: An introduction. Boston, MA: Allyn and Bacon.

16.Garson, D. (2008c). Structural Equation Modeling: Statnotes.

17.Ghost, D. S. F. H., \& Gnanadhas, D. M. E. (2011). Impact of service quality in commercial banks on the customer's satisfaction: An empirical study. International Journal of Multidisciplinary Research, 1(6), 19-37.

18.Grau, E. (2007). Using factor analysis and Cronbach's alpha to ascertain relationships between questions of a dietary behavior questionnaire. In Section on Survey Research Methods (pp. 3104-3110).

19.Gray, B., \& Boshoff, C. (2004). The relationships between service quality, customer satisfaction and buying intentions in the private hospital industry. South African journal of business management, 35(4), 27-37.

20.Hanaysha, J. R., Abdullah, H. H., \& Warokka, A. (2011). Service quality and students' satisfaction at higher learning institutions: The competing dimensions of Malaysian universities' competitiveness. The Journal of Southeast Asian Research, 2011, 1-10.

21.Hallowell, R. (1996). The relationships of customer satisfaction, customer loyalty, and profitability: an empirical study. International journal of service industry management, 7(4), 27-42.

22.Hanif, Muzammil, Sehrish Hafeez, and Adnan Riaz (2010). Factors affecting customer satisfaction. International Research Journal of Finance and Economics, 60, 44-52.

23.Karim, A., \& Chowdhury, T. (2014). Customer Satisfaction on Service Quality in Private Commercial Banking Sector. British Journal of Marketing Studies, 2(2), 1-11.

24.Kiran, K. (2010). Service quality and customer satisfaction in academic libraries: Perspectives from a Malaysian university. Library Review, 59(4), 261-273.

25.Kitapci, Olgun, Ceylan Akdogan, and İbrahim Taylan Dortyol (2014). The Impact of Service Quality Dimensions on Patient Satisfaction, Repurchase Intentions and Word-of-Mouth Communication in the Public Healthcare Industry. Procedia-Social and Behavioral Sciences, 148, 161-169.

26.Malhotra, Naresh K. (1999). Marketing Research, An Applied Orientation, 3rd Edition.

27.Markovic, S., Raspor Jankovic, S. (2013). Exploring the Relationship between Service. Tourism and Hospitality Management, 19(2), 149-164.

28.Mugenda, O. M., \& Mugenda, A. G. (2003). Research Methods: Quantities \& Qualitative Approaches, Nairobi.

29.Munusamy, J., Chelliah, S., \& Mun, H. W. (2010). Service quality delivery and its impact on customer satisfaction in the banking sector in Malaysia. International Journal of Innovation, Management and Technology, 1(4), 398.

30.Naeem, H., Akram, A., \& Saif, M. I. (2009). Service Quality and its impact on Customer Satisfaction: An empirical evidence from the Pakistani banking sector. International Business \& Economics Research Journal (IBER), 8(12).

31.Naik, C. K., Gantasala, S. B., \& Prabhakar, G. V. (2010). Service quality (SERVQUAL) and its effect on customer satisfaction in retailing. European journal of social sciences, 16(2), 231-243.

32.Neuman, W. L., \& Kreuger, L. (2003). Social work research methods: Qualitative and quantitative approaches. Allyn and Bacon.

33.North, A. S., \& Noyes, J. M. (2002). Gender influences on children's computer attitude and cognitions. Computers in Human Behavior, 18(2), 135-150.

34.Nimako, S. G. (2012). Linking quality, satisfaction and behaviour intentions in Ghana's mobile telecommunication industry. European Journal of Business and Management, 4(7), 1-17.

35.Odhiambo, M. R. (2015). Effect of Service Quality on Customer Satisfaction in Banking Industry: A Casestudy of Kenya Commercial Bank (KCB) (Doctoral dissertation, United States International University-Africa).

36.Oh, H. (1999). Service quality, customer satisfaction, and customer value: A holistic perspective. International Journal of Hospitality Management, 18(1), 67-82.

37.Ojo, O. (2010). The relationship between service quality and customer satisfaction in the telecommunication industry: Evidence from Nigeria. BRAND. Broad Research in Accounting, Negotiation, and Distribution, 1(1), 88-100.

38.Özer, Alper, Mehpare Tokay Argan, and Metin Argan (2013). The effect of mobile service quality dimensions on customer satisfaction. Procedia-Social and Behavioral Sciences, 99, 428-438.

39.Pallant, J. (2001). SPSS Survival Guide: A step by step guide to data analysis using SPSS. Australia: Allen \& Unwin.

40.Pandey, D. and Joshi, P.R. (2010). Service Quality and Customer Behavioral Intentions: A Study in the Hotel Industry. California Journal of Operations Management, 8(2), 72-81. 
41.Parasuraman, A., Zeithaml, V. A., \& Berry, L. L. (1985). A conceptual model of service quality and its implications for future research. Journal of marketing, 49(4), 41-50.

42.Pedersen, P.E. and Nysveen, H. (2003). Usefulness and self-expressiveness: extending TAM to explain the adoption of a mobile parking services. In the Proceeding of 16th Beld eCommerce Conference, Bled, Slovenia, June 9-11.

43.Ramsaran-Fowdar, R. R. (2007). Developing a service quality questionnaire for the hotel industry in Mauritius. Journal of Vacation Marketing, 13(1), 19-27.

44.Roy, S. K., \& Ganguli, S. (2008). Service quality and customer satisfaction: An empirical investigation in Indian mobile Telecommunications services. Marketing Management Journal, 18(2), 119-144.

45.Sivadas, E., \& Baker-Prewitt, J. L. (2000). An examination of the relationship between service quality, customer satisfaction, and store loyalty. International Journal of Retail \& Distribution Management, 28(2), 73-82.

46.Survey Software (2014). Retrieved from http://www.surveysystem.com/sscalc.htm.

47.Suthar, B. K., Lathangi, R., \& Pradhan, S. (2014). Impacts of marketing mix and customer perception on brand loyalty. Global journal of finance and management, 6(7), 619-636.

48.Toosi, N. \& Kohanali, R. (2011). The Study of Airline Service Quality in the Qeshm Free Zone by Fuzzy Logic. Journal of Mathematics and Computer Science, 2(1), 171-183.

49. Yang, Z. and Fang, X. (2004). Online service quality dimensions and their relationships with satisfaction: A content analysis of customer reviews of securities brokerage services. International Journal of Service Industry Management, 15(3), 302-326.

50.Zikmund, W.G. (1997). Business Research Methods, Dryden Press, Fort Worth.

51.Zikmund, W.G. (2000). Business research methods. NewYork: The Dryden Press.

52.Zikmund, W.G. (2003). Business research Methods (8th ed.). Cincinnati, OH: Thomson/southwestern. 


\section{Appendix}

\section{(Please tick where appropriate)}

\section{Gender Male ( ) Female ( )}

2. Age (years) Between 20-30 ( ) Between 31-40 ( ) Between 41-50 ( ) 50 and above ()

3. Company Type Telenor ( ) Ufone ( ) Mobilink ( ) Zong ( ) PTCL ( ) Others

4. Customer belongs to Rawalpindi ( ), Islamabad ( ) Others

\begin{tabular}{|c|c|c|c|c|c|c|c|}
\hline $\begin{array}{l}\text { Independent } \\
\text { variables }\end{array}$ & Items & Sources & $\begin{array}{l}\text { Strongly } \\
\text { Disagree }\end{array}$ & Disagree & Neutral & Agree & $\begin{array}{l}\text { Strongly } \\
\text { Agree }\end{array}$ \\
\hline \multirow{5}{*}{$\begin{array}{l}\text { Reliability } \\
\text { (ability to } \\
\text { perform the } \\
\text { expected service } \\
\text { dependably and } \\
\text { accurately) }\end{array}$} & $\begin{array}{l}\text { Staff is Providing the services at } \\
\text { the time Promised. }\end{array}$ & \multirow{5}{*}{$\begin{array}{l}\text { Rooma } \\
\text { Roshnee } \\
\text { Ramsaran } \\
\text {-Fowdar } \\
\text { (July } \\
2006 \text { ) }\end{array}$} & & & & & \\
\hline & $\begin{array}{l}\text { Ideal Telecom industry has } \\
\text { relevant and } \\
\text { information. }\end{array}$ & & & & & & \\
\hline & $\begin{array}{l}\text { Staff has Accurate information } \\
\text { about Telecom services. }\end{array}$ & & & & & & \\
\hline & $\begin{array}{l}\text { Maintenance of error-free records } \\
\text { by Telecom industry staff. }\end{array}$ & & & & & & \\
\hline & $\begin{array}{l}\text { Telecom industry Staff is with } \\
\text { good communication skills. }\end{array}$ & & & & & & \\
\hline \multirow{5}{*}{$\begin{array}{l}\text { Assurance } \\
\text { (courtesy and } \\
\text { knowledge of } \\
\text { staff and } \\
\text { their ability to } \\
\text { inspire trust and } \\
\text { confidence) }\end{array}$} & Courteous employees. & \multirow{5}{*}{$\begin{array}{l}\text { Rooma } \\
\text { Roshnee } \\
\text { Ramsaran } \\
\text {-Fowdar } \\
\text { (July } \\
2006 \text { ) }\end{array}$} & & & & & \\
\hline & $\begin{array}{l}\text { Ability of staff to instill } \\
\text { confidence in customers to trust } \\
\text { company services. }\end{array}$ & & & & & & \\
\hline & $\begin{array}{l}\text { Employees of Telecom industry } \\
\text { are always willing to help } \\
\text { customer. }\end{array}$ & & & & & & \\
\hline & $\begin{array}{l}\text { Making customer's feel safe in } \\
\text { their transactions. }\end{array}$ & & & & & & \\
\hline & $\begin{array}{l}\text { Knowledgeable staff who can } \\
\text { answer customer's questions. }\end{array}$ & & & & & & \\
\hline \multirow{5}{*}{$\begin{array}{l}\text { Tangibility } \\
\text { (physical } \\
\text { facilities, } \\
\text { equipment and } \\
\text { appearance of } \\
\text { personnel) }\end{array}$} & Modern-looking equipment. & \multirow{5}{*}{$\begin{array}{l}\text { Rooma } \\
\text { Roshnee } \\
\text { Ramsaran } \\
\text {-Fowdar } \\
\text { (July } \\
2006 \text { ) }\end{array}$} & & & & & \\
\hline & Visually appealing facilities. & & & & & & \\
\hline & $\begin{array}{l}\text { Convenient access to Service } \\
\text { Centers. }\end{array}$ & & & & & & \\
\hline & $\begin{array}{l}\text { Visually appealing brochures, } \\
\text { pamphlets, etc. }\end{array}$ & & & & & & \\
\hline & Neat appearance of employees. & & & & & & \\
\hline \multirow{5}{*}{$\begin{array}{l}\text { Empathy } \\
\text { (caring, } \\
\text { individualized } \\
\text { attention } \\
\text { provided to } \\
\text { customer by } \\
\text { Telecom } \\
\text { industry staff) }\end{array}$} & $\begin{array}{l}\text { Understanding the customer's } \\
\text { requirements. }\end{array}$ & \multirow{5}{*}{$\begin{array}{l}\text { Rooma } \\
\text { Roshnee } \\
\text { Ramsaran } \\
\text {-Fowdar } \\
\text { (July } \\
2006 \text { ) }\end{array}$} & & & & & \\
\hline & $\begin{array}{l}\text { Giving special attention to the } \\
\text { customer. }\end{array}$ & & & & & & \\
\hline & Listening carefully to complaints. & & & & & & \\
\hline & $\begin{array}{l}\text { Variety of basic products and } \\
\text { services offered. }\end{array}$ & & & & & & \\
\hline & Problem-solving abilities of staff. & & & & & & \\
\hline \multirow{5}{*}{$\begin{array}{l}\text { Responsiveness } \\
\text { (willingness to } \\
\text { help customers } \\
\text { and } \\
\text { provide prompt } \\
\text { service) }\end{array}$} & $\begin{array}{l}\text { Keeping customers informed } \\
\text { about when the Service will be } \\
\text { performed. }\end{array}$ & \multirow{5}{*}{$\begin{array}{l}\text { Rooma } \\
\text { Roshnee } \\
\text { Ramsaran } \\
\text {-Fowdar } \\
\text { (July } \\
\text { 2006) }\end{array}$} & & & & & \\
\hline & $\begin{array}{l}\text { Availability of staff to provide } \\
\text { service. }\end{array}$ & & & & & & \\
\hline & $\begin{array}{l}\text { Responsiveness to customers' } \\
\text { requests. }\end{array}$ & & & & & & \\
\hline & $\begin{array}{l}\text { Employees of Ideal } \\
\begin{array}{l}\text { Industry will inform } \\
\text { customer }\end{array} \\
\text { about any changes in their } \\
\text { services. }\end{array}$ & & & & & & \\
\hline & $\begin{array}{l}\text { Employees of Telecom Industry } \\
\text { will recommend appropriate } \\
\text { products or services to the } \\
\text { customer. }\end{array}$ & & & & & & \\
\hline
\end{tabular}


Appendix (cont.)

\begin{tabular}{|c|c|c|c|c|c|c|c|}
\hline $\begin{array}{c}\text { Independent } \\
\text { variables }\end{array}$ & Items & Sources & $\begin{array}{l}\text { Strongly } \\
\text { Disagree }\end{array}$ & Disagree & Neutral & Agree & $\begin{array}{c}\text { Strongly } \\
\text { Agree }\end{array}$ \\
\hline \multirow[t]{3}{*}{$\begin{array}{l}\text { Customer } \\
\text { Satisfaction }\end{array}$} & $\begin{array}{l}\text { How satisfied are you with } \\
\text { Telecom industry staff that they } \\
\text { are Never being too busy to } \\
\text { respond to your requests. }\end{array}$ & $\begin{array}{l}\text { Roger } \\
\text { Hallowell } \\
(1995)\end{array}$ & & & & & \\
\hline & $\begin{array}{l}\text { How satisfied are you with } \\
\text { Telecom industry staff that they } \\
\text { have Knowledge about the } \\
\text { products and services of } \\
\text { company. }\end{array}$ & $\begin{array}{l}\text { Roger } \\
\text { Hallowell } \\
(1995)\end{array}$ & & & & & \\
\hline & $\begin{array}{l}\text { How satisfied are you with } \\
\text { Telecom industry staff that they } \\
\text { have Provided easy access to } \\
\text { needed information }\end{array}$ & $\begin{array}{l}\text { Roger } \\
\text { Hallowell } \\
(1995)\end{array}$ & & & & & \\
\hline & $\begin{array}{l}\text { How satisfied are you with } \\
\text { Telecom industry staff Ability to } \\
\text { answer your questions. }\end{array}$ & $\begin{array}{l}\text { Roger } \\
\text { Hallowell } \\
(1995)\end{array}$ & & & & & \\
\hline & $\begin{array}{l}\text { How satisfied are you with } \\
\text { Telecom industry staff that they } \\
\text { are Providing convenient branch } \\
\text { locations? }\end{array}$ & $\begin{array}{l}\text { Roger } \\
\text { Hallowell } \\
(1995)\end{array}$ & & & & & \\
\hline & $\begin{array}{l}\text { How satisfied are you with } \\
\text { Telecom industry staff that they } \\
\text { are Maintaining clean and } \\
\text { pleasant service center facilities. }\end{array}$ & $\begin{array}{l}\text { Roger } \\
\text { Hallowell } \\
(1995)\end{array}$ & & & & & \\
\hline & $\begin{array}{l}\text { How satisfied are you with } \\
\text { Telecom industry staff that they } \\
\text { have a concerned and caring } \\
\text { attitude? }\end{array}$ & $\begin{array}{l}\text { Roger } \\
\text { Hallowell } \\
(1995)\end{array}$ & & & & & \\
\hline & $\begin{array}{l}\text { How satisfied are you with } \\
\text { Telecom industry staff, that they } \\
\text { have Maintained a professional } \\
\text { appearance. }\end{array}$ & $\begin{array}{l}\text { Roger } \\
\text { Hallowell } \\
(1995)\end{array}$ & & & & & \\
\hline & $\begin{array}{l}\text { How satisfied are you with } \\
\text { Telecom industry staff, that they } \\
\text { are Being capable and competent. }\end{array}$ & $\begin{array}{l}\text { Roger } \\
\text { Hallowell } \\
(1995)\end{array}$ & & & & & \\
\hline
\end{tabular}

